Dr. J. Bronowski's address to the Seventh Present Question Conference brought out very clearly both the dangers of the present situation and the implications for the scientific man. Vindicating, like Sir John Cockcroft before him, the scientist from the charge of irresponsibility in his scientific work, Dr. Bronowski insists that the great responsibility of the scientific man to-day is to become a teacher to the whole community, and to help his fellow men to understand clearly the implications of the forces which science has released and the changes science is bringing about. Only so is there any hope of society acquiring the wisdom which is required for it to regain control over events, and to choose those directions which tend to good and turn from those that do not. Dr. Conant's addresses should inspire an even wider circle of scientific men and other scholars to turn to the imaginative and constructive thinking out of which will emerge the new institutions of Anglo-American co-operation, whether in science, in the universities or in world affairs generally.

\section{ENTOMOLOGY AND CITRUS FRUIT PRODUCTION}

\section{Citrus Entomology in the Middle East}

With Special References to Egypt, Iran, Irak, Palestine, Syria, Turkey. By F. S. Bodenheimer. Pp. xii+663. ('s-Gravenhage : Dr. W. Junk, 1951.) n.p. DROF. F. S. BODENHEIMER'S work is a very thorough compilation of almost all that has been published in the literature, since it covers all the living organisms of the animal kingdom which are related to the now almost universally important problem of citrus fruit production. The part played by insects being by far the most predominant, the author gives an exhaustive account of the results of investigations on the insect pests in the countries surrounding the eastern Mediterranean. In chapters on flies (Diptera), scale insects and thrips, Prof. Bodenheimer fully discusses the ecology of each major pest, selecting not only good and concise descriptions of the species but using also the most recently adopted nomenclature-with keys for the identification of the major groups, as well as of the species. The geographical distribution, a list of the host plants, the seasonal history, the correlation of the development of the insect to temperature and humidity (illustrated by ecoclimograms), threshold of development, thermal constant and the number of generations are given for every important species. Reproduction and productivity, differences between summer and winter eggs, sexual fluctuations, biology of nutrition, fluctuation of populations as a result of change in the nutritional properties of the soil, and numerous other details are discussed and illustrated by a large number of useful tables and graphs. The natural enemies, parasites and predators are studied and supported by judicious conclusions as regards their varying importance based on their biology.

It is to be regretted that Prof. Bodenheimer's book has been considerably retarded owing to the Second World War, for during the past few years the measures of control, particularly those dealing with the most disastrous species of scale insects, have undergone many improvements.
It is unfortunate and regrettable, also, that the list of the most important literature at the end of each chapter does not extend beyond 1946, when the text (Prof. Bodenheimer in his introduction admits that the manuscript of the book was sent to Amsterdam during the early part of the War) is said to have been entirely revised. Moreover, earlier papers such as the valuable piece of research by Dr. A. D. Hanna, on Ceratitis capitata Wied. (Bull. Soc. Fouad I d'Entom., 22 (1938), 31 (1947) and 32 (1948)), are not mentioned in the bibliography. The completion of the work in this respect would have considerably enhanced the value of the book. In my opinion, it would have been preferable to combine the bibliography of each chapter at the end of the volume, and an alphabetical index of the names of insects dealt with should have been added.

In spite of these remarks, Prof. Bodenheimer's "Citrus Entomology" is an authoritative and indispensable book, being written with a breadth of view only to be acquired by a truly scientific outlook. I recommend it not only to agricultural research institutes and citrus farmers but also to entomologists the world over.

H. C. Efflatoun

\section{PARASITES AND PARASITISM}

\section{Parasitic Animals}

By Dr. Geoffrey Lapage. (Cambridge Library of Modern Science.) Pp. xxi $+351+8$ plates. (Cambridge: At the University Press, 1951.) 21s. net.

THIS is not intended to be a text-book of parasitology, but it does contain a considerable amount of factual information concerning a number of forms, mostly those affecting man or domesticated animals. It could only have been written by one who had, like Dr. G. Lapage, devoted years to the study of parasites and parasitism with its manifold practical and theoretical implications. It may be regarded as almost an ecological study of highly specialized animals living in remarkable environments and a discussion of the general principles underlying the relationship. The author makes a plea, that in considering the many aspects of the subject, the student should try to overcome the prejudice resulting from a knowledge of the diseases, pain and loss caused by parasites and should turn to the beauty of the remarkable adaptations they illustrate.

From the method of approach, the arrangement of the contents can be neither that of systematic zoology nor of medical practice. Dr. Lapage has, with success and as the result of the exercise of much thought and ingenuity, produced a logical sequence in the method of presentation. The methods of contact between parasite and host and the ways in which the parasite reaches its resting place are arranged and discussed in a series of examples of increasing complexity. Similarly, the descriptions of life-histories of parasites are not only divided into chapters according to whether one or more than one host is involved, but also within each chapter the life-histories are arranged in series beginning with the most simple and passing by steps to the more and more complex. With this factual material for reference, the author considers the effect of the parasitic mode of life, first upon the parasite itself and secondly upon the host. This naturally leads on to more general questions such as tissue reactions and immunity, and other aspects of the host-parasite 